\title{
The Activation of Inositol Phospholipid Metabolism as a Signal-Transducing System for Excitatory Amino Acids in Primary Cultures of Cerebellar Granule Cells
}

\author{
F. Nicoletti, J. T. Wroblewski, A. Novelli, H. Alho, A. Guidotti, and E. Costa \\ Fidia-Georgetown Institute for the Neurosciences, Georgetown University Medical School, Washington, DC 20007
}

L-Glutamic, L-aspartic acids and a number of their structural analogs, including quisqualic, kainic, ibotenic, quinolinic, and $N$-methyl-D-aspartic (NMDA) acids, increase inositol phospholipid hydrolysis when added to primary cultures of cerebellar granule cells, as is reflected by an enhanced formation of ${ }^{3} \mathrm{H}$ inositolmonophosphate $\left({ }^{3} \mathrm{H}-\mathrm{IP}_{1}\right)$ in the presence of $\mathrm{Li}^{+}$. $\mathrm{L}-\mathrm{Glu}$ tamic acid also enhances the formation of the initial products of inositol phospholipid hydrolysis, ${ }^{3} \mathrm{H}$-inositoldi- $\left({ }^{3} \mathrm{H}-\mathrm{IP}_{2}\right)$ and triphosphate $\left({ }^{3} \mathrm{H}-\mathrm{IP}_{3}\right)$. In the absence of extracellular $\mathrm{Ca}^{2+}$, L-glutamic acid fails to enhance ${ }^{3} \mathrm{H}-\mathrm{IP}_{1}$ formation, but still increases ${ }^{3} \mathrm{H}-\mathrm{IP}_{2}$ and ${ }^{3} \mathrm{H}-\mathrm{IP} \mathrm{P}_{3}$ formation.

The stimulation of ${ }^{3} \mathrm{H}-\mathrm{IP}$, formation elicited by L-glutamic acid is reduced by DL-2-amino-5-phosphonovaleric acid (APV) and $\gamma$-glutamylglycine and, to a lesser extent, by 2,3-cis-piperidindicarboxylic acid (PDA). The stimulation of ${ }^{3} \mathrm{H}-\mathrm{IP}_{\mathbf{1}}$ formation by kainic acid is antagonized by PDA and $\gamma$-glutamylglycine, but it is almost unaffected by APV. The increase in ${ }^{3} \mathrm{H}-1 P_{1}$ formation elicited by quisqualic acid is not reduced by any of the dicarboxylic amino acid receptor antagonists that we have tested.

We conclude that different subtypes of excitatory amino acid recognition sites are associated with inositol phospholipid metabolism in primary cultures of cerebellar granule cells.

Although the dicarboxylic amino acid recognition sites located in synaptic membranes have been extensively studied (for a review, see Foster and Fagg, 1984), little is known about the molecular process operative in the transduction of these chemical signals into a specific neuronal response. In rat hippocampal slices, the activation of specific dicarboxylic amino acid recognition sites by ibotenic acid enhances the hydrolysis rate of membrane inositol phospholipids (Nicoletti et al., 1986). Glutamic acid has been found to increase phosphatidylinositol turnover rate in the insect flight muscle (for a review, see Michell, 1975), but it has failed to induce important changes in phosphatidylinositol metabolism in slices from mammalian brain (Brown et al., 1984). However, an accurate assessment of the action of glutamic and aspartic acids on phosphatidylinositol turnover in brain slices is impaired by neuronal and glial uptake and metabolism of these amino acids.

To investigate whether dicarboxylic amino acids change membrane inositol phospholipid hydrolysis, we have used glialfree primary cultures of cerebellar granule cells. These cells have been considered reliable models for the investigation of excitatory amino acid receptor function because they use glutamic acid as neurotransmitter (Sandoval and Cotman, 1978) and they

Received June 27, 1985; revised Oct. 22, 1985; accepted Dec. 30, 1985.

Correspondence should be addressed to Dr. Erminio Costa, Fidia-Georgetown Institute for the Neurosciences, Georgetown University Medical School, 3900 Reservoir Road, Washington, DC 20007.

Copyright (c) 1986 Society for Neuroscience $0270-6474 / 86 / 071905-07 \$ 02.00 / 0$ respond to the application of glutamic, aspartic, and kainic acids with an activation of guanylate cyclase (Novelli et al., unpublished observations).

\section{Materials and Methods}

\section{Cell cultures}

Cerebellar granule cells were obtained from 8-d-old rats, as described by Gallo et al. (1982). In brief, cells were resuspended and seeded in the following culture medium: Basal Eagle's Medium (BME; Flow Labs), $10 \%$ fetal calf serum (FCS; Gibco), $25 \mathrm{~mm} \mathrm{KCl}, 2 \mathrm{~mm}$ glutamine, and $100 \mu \mathrm{g} / \mathrm{ml}$ gentamycin (Gibco), successively plated $\left(2.5 \times 10^{6} \mathrm{cells} / \mathrm{dish}\right)$ onto $35 \mathrm{~mm}$ Falcon dishes coated with poly-L-lysine, $5 \mu \mathrm{g} / \mathrm{ml}$, and incubated at $37^{\circ} \mathrm{C}$ in a humidified atmosphere of $5 \% \mathrm{CO}_{2} / 95 \%$ air. Cytosine arabinofuranoside (Ara-C; $10 \mu \mathrm{M}$ ) was added after $16 \mathrm{hr}$ of culture to inhibit the replication of nonneuronal cells. Cerebellar astrocytic cultures were prepared as described by Woodhams et al. (1981). The culture medium was BME containing $10 \%$ FCS, 2 mM glutamine, and $100 \mathrm{mg} / \mathrm{ml}$ gentamycin. The $\mathrm{KCl}$ concentration in this medium was $4.7 \mathrm{~mm}$ and no Ara-C was added to these cultures. Neuronal and astrocytic cultures have been characterized by immunocytochemistry.

\section{Immunocytochemistry}

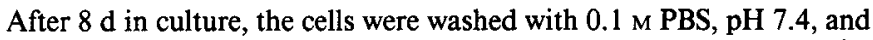
then fixed with $4 \%$ formaldehyde plus $0.1 \%$ glutaraldehyde in PBS for $10 \mathrm{~min}$ at room temperature. The cells were first incubated for $20 \mathrm{~min}$ with a 1:10 dilution of normal goat antiserum (NGS) and then incubated with specific antisera at $4^{\circ} \mathrm{C}$ for $24 \mathrm{hr}$ in PBS containing $0.1 \%$ saponin (Sigma, St. Louis) and $0.1 \%$ NGS. This incubation was terminated by several washings followed by incubation with secondary antibodies PBS/ saponin/NGS for $30 \mathrm{~min}$. After washing, the cells were coverslipped with buffered glycerol and viewed with a fluorescence microscope (Leitz). Polyclonal rabbit antiserum to glial fibrillary acid protein (GFAP; Dako) was diluted 1:1000; sheep antiserum to glutamic acid decarboxylase (GAD, EC 4.1.1.15; a gift from Dr. J. Kopin) was diluted 1:800; monoclonal mouse antisera to phosphorylated and nonphosphorylated neurofilaments (Sternberger-Mayer) were diluted 1:2000. Secondary antibodies were affinity-purified and conjugated to fluorescein isothiocyanate (FITC) goat anti-mouse IgG (1:100; Cappel) and rhodamine isothiocyanate (RITC) goat anti-rabbit IgG (1:100; Jackson Immunoresearch).

For double immunofluorescence staining, the cells were incubated with a mixture of both primary antibodies at the same dilutions as above and incubated after washings with 2 appropriate antibodies with different fluorescent labels, so that glial cells were emitting red (RITC) and neuronal cells green (FITC) fluorescence. [For specificity, culture dishes were processed in the full immunohistochemical sequence with one (or both) primary antiserum deleted or replaced with normal rat serum. No detectable staining was observed in these conditions.]

\section{Measurement of inositol phospholipid hydrolysis}

The rate of inositol phospholipid hydrolysis was estimated by measuring the formation of ${ }^{3} \mathrm{H}$-inositolmonophosphate $\left({ }^{3} \mathrm{H}-\mathrm{IP} \mathrm{P}_{1}\right)$ in the presence of $\mathrm{Li}^{+}$, which blocks the conversion of $\mathrm{IP}_{1}$ into free inositol (Allison et al., 1976; Berridge et al., 1982). Culture dishes with 8-10-d-old cells received $1 \mathrm{ml}$ fresh medium containing $0.3 \mu \mathrm{M}$ myo-2- ${ }^{3} \mathrm{H}$-inositol (New England Nuclear; specific activity $16.5 \mathrm{Ci} / \mathrm{mmol}$ ) to label membrane 
Table 1. Stimulation of ${ }^{3} \mathrm{H}-\mathrm{IP}{ }_{1},{ }^{3} \mathrm{H}-\mathrm{IP}_{2}$, and ${ }^{3} \mathrm{H}-\mathrm{IP}_{3}$ formation elicited by L-glutamic acid in primary cultures of cerebellar granule cells in the presence or absence of extracellular $\mathrm{Ca}^{2+}$

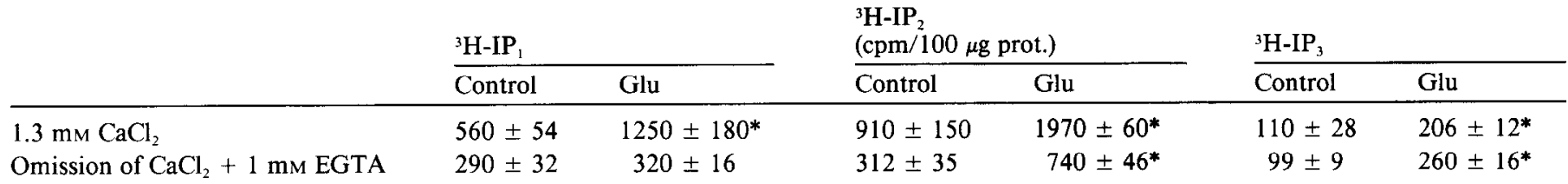

Cerebellar granule cells were incubated for $2 \mathrm{~min}$ in the presence or absence of $50 \mu \mathrm{M} \mathrm{L-glutamic} \mathrm{acid} \mathrm{(Glu).}$

$* p<0.01$, compared with control values.

inositol phospholipids. Twenty-four hours later, the dishes were washed 3 times with $900 \mu \mathrm{l} \mathrm{Krebs} / \mathrm{Hensleit}$ buffer $(\mathrm{NaCl}, 118 \mathrm{~mm} ; \mathrm{KCl}, 4.7$ $\mathrm{mm} ; \mathrm{CaCl}_{2}, 1.3 \mathrm{~mm} ; \mathrm{KH}_{2} \mathrm{PO}_{4}, 1.2 \mathrm{~mm} ; \mathrm{MgSO}_{4}, 1.2 \mathrm{~mm} ; \mathrm{NaHCO}_{3}, 25$ $\mathrm{mM}$; glucose, $11.7 \mathrm{~mm}$ ) containing $7 \mathrm{mM} \mathrm{LiCl}$, equilibrated with $95 \%$ $\mathrm{O}_{2} / 5 \% \mathrm{CO}_{2}$ to a final $\mathrm{pH}$ of 7.4 , and prewarmed at $37^{\circ} \mathrm{C}$. The cells were then incubated with $900 \mu \mathrm{l}$ of buffer at $37^{\circ} \mathrm{C}$ for $15 \mathrm{~min}$ prior to drug addition and then for an additional $20 \mathrm{~min}$ in the presence of dicarboxylic amino acid receptor agonists and antagonists. At the end of the incubation, the buffer was removed by aspiration, $0.3 \mathrm{ml}$ ice-cold water was added, and the reaction (release of ${ }^{3} \mathrm{H}-\mathrm{IP}$, from membrane phospholipids) was stopped by freezing the dishes on dry ice. The cells were harvested and the suspension was added to $0.9 \mathrm{ml}$ chloroform $/ \mathrm{methanol}$ (1:2). After further addition of $0.3 \mathrm{ml}$ water and $0.3 \mathrm{ml}$ chloroform, the suspension was centrifuged at $500 \times g$ for 2 min to facilitate phase separation. The amount of ${ }^{3} \mathrm{H}-\mathrm{IP}$, present in the aqueous phase was estimated as described by Berridge et al. (1982). Eight hundred microliters of aqueous phase (diluted 1:3 with water) were added to columns containing $1 \mathrm{ml}$ of Dowex $1 \times 8$ resin $(100-200$ mesh, formate form; Bio Rad) and the phosphate esters were eluted by stepwise addition of formate solutions of increasing strength. Glycerophosphoinisitol and inositol 1:2 cyclic phosphate were eluted with 5 mM sodium

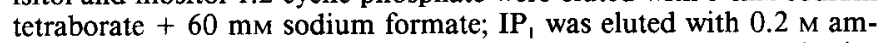
monium formate $+0.1 \mathrm{M}$ formic acid (see Note); the more polar inositoldi- $\left(\mathrm{IP}_{2}\right)$ and inositoltri- $\left(\mathrm{IP}_{3}\right)$ phosphates were eluted with $0.4 \mathrm{M}$ ammonium formate $+0.1 \mathrm{M}$ formic acid and $1 \mathrm{M}$ ammonium formate $+0.1 \mathrm{M}$ formic acid, respectively. The fractions were collected and the radioactivity measured by liquid scintillation spectrometry. Proteins were measured according to Lowry et al. (1951). [Note: The elution prufile of inositol monophosphate from the anion exchangc column was monitored using inositol-2-monophosphate as an external standard. Twenty microliters of the effluent from the Dowex column were injected into a flow-injection analyzer system consisting of a pump, loop valve, alkaline phosphatase-loaded column, mixing tee, reagent pump, and spectrophotometer. The enzyme-loaded column $(3 \mathrm{~cm} \times 4 \mathrm{~mm})$ contained 100 Sigma units of calf intestinal alkaline phosphates adsorbed to phenoxyacetylcellulose. The column effluent was mixed with a stream containing $0.4 \%$ ammonium molybdate in $1 \mathrm{~m}$ nitric acid. The formation of unreduced phosphonomolybdate complex was monitored at $360 \mathrm{~nm}$.]

Table 2. Stimulation of ${ }^{3} \mathrm{H}-\mathrm{IP}_{1}$ accumulation elicited by some agonists of dicarboxylic amino acid receptors

\begin{tabular}{lc}
$\begin{array}{l}\text { Dicarboxylic amino acid } \\
\left(10^{-4} \mathrm{M}\right)\end{array}$ & $\begin{array}{l}{ }^{3} \mathrm{H}-\mathrm{IP}_{1} \text { accumulation } \\
(\mathrm{cpm} / 100 \mu \mathrm{g} \text { prot. })\end{array}$ \\
\hline None & $460 \pm 11(12)$ \\
L-Glutamic acid & $2100 \pm 83^{*}(11)$ \\
Quisqualic acid & $1400 \pm 40^{*}(10)$ \\
Kainic acid & $1100 \pm 84^{*}(6)$ \\
L-Aspartic acid & $920 \pm 43^{*}(6)$ \\
Ibotenic acid & $760 \pm 51^{*}(6)$ \\
NMDA & $580 \pm 27^{*}(6)$ \\
Quinolinic acid & $590 \pm 28^{*}(4)$
\end{tabular}

Values are mean \pm SEM of 4-12 determinations ( $N$ in parentheses).

${ }^{*} p<0.01$, significantly different from basal values when compared to Dunnett's $t$ test.

\section{Measurement of glutamic acid release}

Glutamic acid was measured by HPLC essentially as described by Einarsson et al. (1983). Aliquots of the incubation medium containing the released glutamic acid were derived with 9-fluorenymethyl chloroformate (Sigma), extracted twice with pentane, and the water phase was injected. A $150 \times 4.6 \mathrm{~mm}$ I.D. $5 \mu \mathrm{m}$ Altex Ultrasphere ODS column was used. The eluent contained $12 \%$ acetonitrile and $30 \%$ methanol in $50 \mathrm{~mm}$ Na-acetate buffer, $\mathrm{pH} 4.0$. Between injections, the columns were washed with $50 \%$ acetonitrile in Na-acetate buffer. The fluorometric detector (Farrand) was equipped with a $254 \mathrm{~nm}$ interference excitation filter and a $300 \mathrm{~nm}$ high-pass emission filter.

\section{Chemicals}

L-Glutamic, L-aspartic, quisqualic, kainic, ibotenic, $N$-methyl-D-aspartic (NMDA), quinolinic, DL-aminophosphonovaleric (APV), and DLaminophosphonobutyric (APB) acids, -glutamatedielhylester (GDEE) were purchased from Sigma. 2,3-Cis-piperidin dicarboxylic acid (PDA) and -glutamylglycine were purchased from Cambridge Research Biochemicals.

\section{Results}

We established that neuronal cultures contain more than $97 \%$ neurons and only a few (less than 3\%) glial cells (Fig. 1). Approximately $92 \%$ of the neuronal cells have been morphologically identificd as granule cells. Accordingly, these cultured cells have a high density of GABA, benzodiazepines, and $t$-butylbicyclophosphate recognition sites (Gallo et al., 1985), which are present also in granule cells in vivo. GABAergic neurons (mostly basket and Golgi cells), identified by specific GAD immunostaining, are also present but do not exceed $5 \%$ of the cell population (Fig. 2).

Initial experiments were performed to determine whether the stimulatory action of excitatory amino acids on inositol phospholipid hydrolysis was dependent on incubation time. When granule cells were incubated in the presence of $10^{-5} \mathrm{M} \mathrm{L}$-glutamic or kainic acids, ${ }^{3} \mathrm{H}-\mathrm{IP}_{1}$ formation increased linearly during the first $5 \mathrm{~min}$. ${ }^{3} \mathrm{H}-\mathrm{IP}_{1}$ accumulation pcaked after $20 \mathrm{~min}$ and appeared to decrease slightly after $40 \mathrm{~min}$ of incubation (Fig. 3). Hence, an incubation time of $20 \mathrm{~min}$ was used routinely to study the stimulation of ${ }^{3} \mathrm{H}-\mathrm{IP} \mathrm{P}_{1}$ formation. L-Glutamic acid also stimulated the formation of ${ }^{3} \mathrm{H}-\mathrm{IP}_{2}$ and ${ }^{3} \mathrm{H}-\mathrm{IP}_{3}$ after $2 \mathrm{~min}$ of incubation (Table 1). No changes in ${ }^{3} \mathrm{H}-\mathrm{IP}_{2}$ or ${ }^{3} \mathrm{H}-\mathrm{IP}_{3}$ were detectable when cells were incubated for $20 \mathrm{~min}$ in the presence of L-glutamic acid (data not shown). The absence of extracellular $\mathrm{Ca}^{2+}$ (achieved by the omission of $\mathrm{Ca}^{2+}$ from the incubation buffer + addition of $1 \mathrm{~mm}$ EGTA) abolished, as expected, the increase in ${ }^{3} \mathrm{H}$-IP formation elicited by L-glutamic acid (Table 1). However, the stimulation of ${ }^{3} \mathrm{H}-\mathrm{IP}_{2}$ and ${ }^{3} \mathrm{H}-\mathrm{IP}_{3}$ by L-glutamic acid was substantially preserved in the absence of extracellular $\mathrm{Ca}^{2+}$ (Table 1).

Pharmacology of the increase in ${ }^{3} \mathrm{H}-\mathrm{IP}$, formation elicited by excitatory amino acids in primary cultures of cerebellar granule cells

All the excitatory amino acids that we have tested enhanced ${ }^{3} \mathrm{H}-\mathrm{IP}_{1}$ formation in $\mathrm{Li}^{+}$-treated primary cultures of cerebellar 

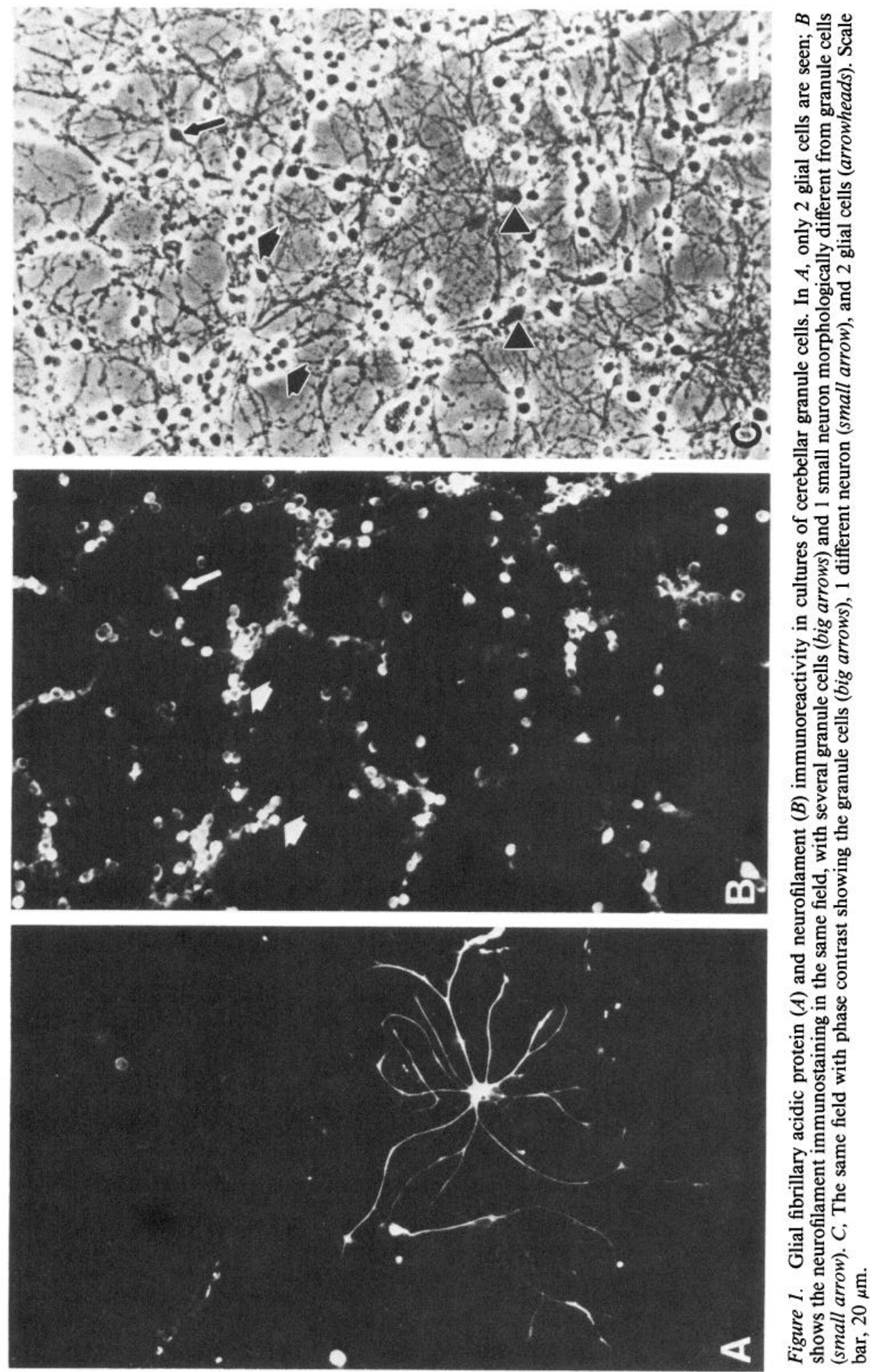
Figure 2. Micrograph from cerebellar cultured cells showing GAD immunostaining. No staining was associated with granule cells, whereas there are 2 positive GAD interneurons ( $a r$ rows) and GAD-positive axons and terminals. Bar $=10 \mu \mathrm{m}$.

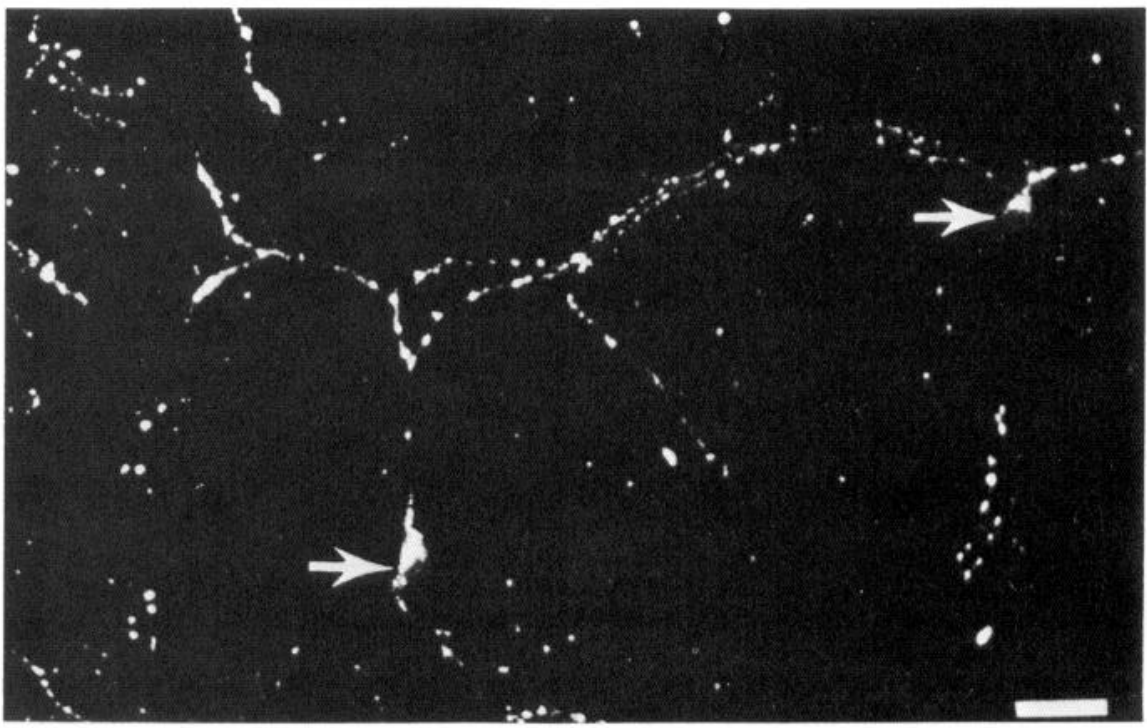

granule cells (Table 2, Fig. 4). The apparent $\mathrm{EC}_{50}$ values estimated from the concentration-response curves presented in Figure 2 range from 10 to $20 \mu \mathrm{M}$ for L-glutamic, L-aspartic, and kainic acids, are approximately $50 \mu \mathrm{M}$ for quisqualic acid, and $200 \mu \mathrm{M}$ for NMDA. Based on the increase in ${ }^{3} \mathrm{H}-\mathrm{IP}_{1}$ formation elicited by various concentrations of excitatory amino acids, their rank order of potency is L-glutamic $>$ quisqualic $>$ kainic $>$ L-aspartic > NMDA.

The stimulation of ${ }^{3} \mathrm{H}-\mathrm{IP}_{1}$ formation by L-glutamic acid is not affected by the concurrent presence of atropine and phentolamine, which antagonize muscarinic cholinergic and $\alpha_{1}$-adrenergic receptors, respectively (data not shown). This evidence suggests that the stimulation of ${ }^{3} \mathrm{H}-\mathrm{IP}_{1}$ formation elicited by $\mathrm{L}-$ glutamic acid is not mediated indirectly through muscarinic or $\alpha_{1}$-adrenergic receptors which, in the CNS, are coupled with inositol phospholipid metabolism (for a review, see Michell, 1975). The increase in ${ }^{3} \mathrm{H}-\mathrm{IP}_{1}$ formation elicited by L-glutamic acid is significantly reduced by APV, $\gamma$-glutamylglycine, or PDA, which are reported to act as antagonists at excitatory amino acid recognition sites (see Foster and Fagg, 1984). Specifically, APV is much more potent than PDA in antagonizing the stimulatory action of L-glutamic acid on inositol phospholipid hydrolysis (Table 3, Fig. 5). APV also antagonizes the stimulation of ${ }^{3} \mathrm{H}$ $\mathrm{IP}_{1}$ formation by L-aspartic acid (Table 3 ). The stimulatory action of low concentrations $\left(10^{-5} \mathrm{M}\right)$ of kainic acid on ${ }^{3} \mathrm{H}-\mathrm{IP}_{1}$ formation is antagonized by PDA and $\gamma$-glutamylglycine, but is almost insensitive to the APV inhibition (Table 3, Fig. 4). This evidence suggests that kainic acid acts through a different excitatory amino acid receptor, at which PDA acts as a preferential antagonist. However, an accurate estimation of the excitatory action of kainic acid is difficult to achieve, since kainic acid markedly stimulates glutamate release in cerebellar granule cells (Fig. 6). An enhanced release of glutamic acid might contribute to the accumulation of ${ }^{3} \mathrm{H}-\mathrm{IP}_{1}$ elicited by concentrations of kainic acid higher than $5 \times 10^{-5} \mathrm{M}$. Consistent with this hypothesis is that APV fails to antagonize the action of $10^{-5} \mathrm{M}$ kainic acid but is as effective as PDA in reducing the increase in ${ }^{3} \mathrm{H}-\mathrm{IP}_{1}$ formation elicited by $10^{-4} \mathrm{M}$ kainic acid (Table 3 ).

The accumulation of ${ }^{3} \mathrm{H}-\mathrm{IP}_{1}$ elicited by quisqualic acid is not reduced by any of the dicarboxylic amino acid receptor antagonists that we have tested (Table 3 ). In addition, the action of quisqualic acid fails to be reduced by the GABA receptor blocker bicuculline $\left(10^{-5} \mathrm{M}\right)$ (data not shown). This evidence suggests that the action of quisqualic acid is not mediated by its decarboxylation into the GABA-mimetic drug quisqualamine.

APB is ineffective in antagonizing the accumulation of ${ }^{3} \mathrm{H}$ IP , elicited by the addition of excitatory amino acid receptor agonists to primary cultures of cerebellar granule cells (Table 3). GDEE, which is reported to act as an excitatory amino acid receptor antagonist (for a review, see Foster and Fagg, 1984), not only fails to antagonize, but even potentiates the increase in ${ }^{3} \mathrm{H}-\mathrm{IP}_{1}$ formation elicited by L-glutamic and quisqualic acids

Table 3. ${ }^{3} \mathrm{H}-\mathrm{IP}_{1}$ accumulation elicited by dicarboxylic amino acids in the presence of various transmitter receptor antagonists

${ }^{3} \mathrm{H}-\mathrm{IP}$, formation (cpm/100 $\mu \mathrm{g}$ proteins)

Dicarboxylic amino acid receptor antagonist

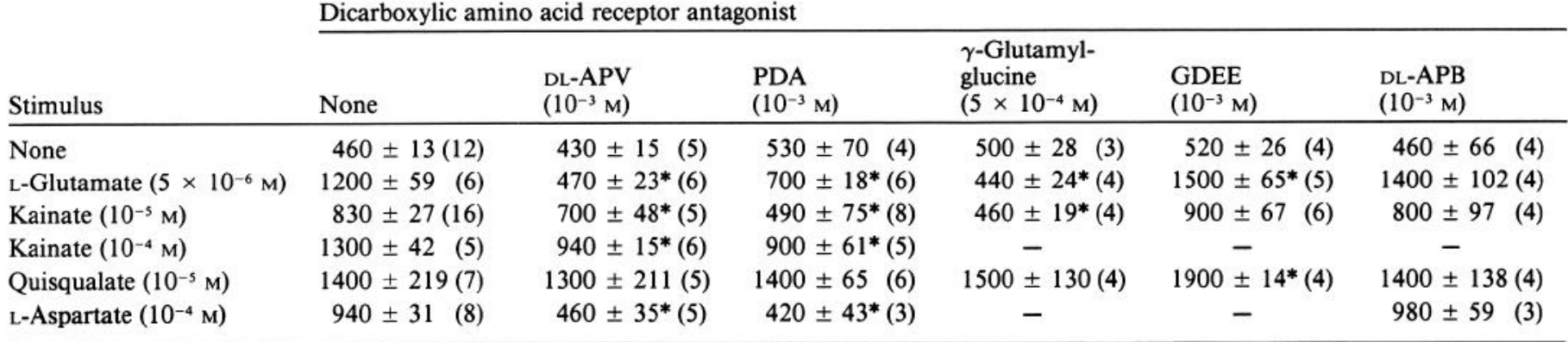

Antagonists were added to the incubation buffer 5 min prior to agonists. Values are mean \pm SEM of 3-16 determinations ( $N$ in parentheses).

${ }^{*} p<0.01$, significantly different from basal values when compared with Dunnett's $t$ test. 


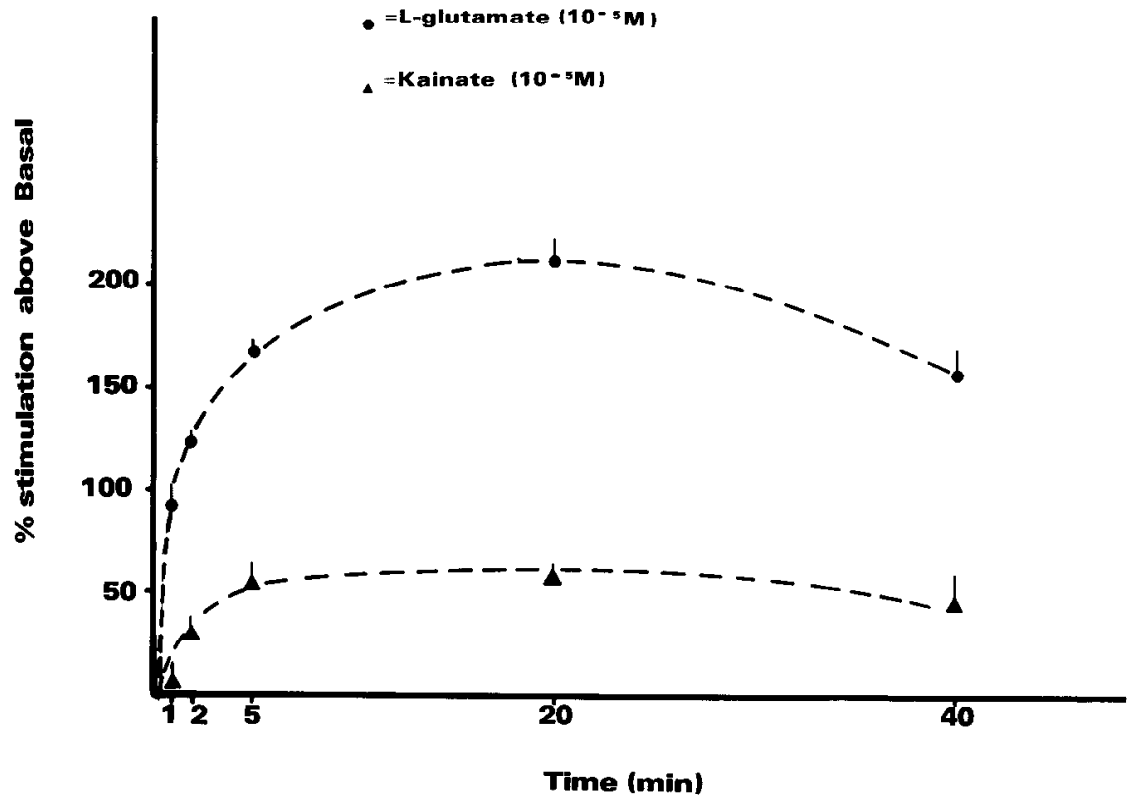

Figure 3. Time-dependent accumulation of ${ }^{3} \mathrm{H}-\mathrm{IP}_{1}$ (expressed as percent stimulation above basal) elicited by L-glutamic and kainic acids in primary cultures of cerebellar granule cells. Control values do not change as a function of the incubation time.

(Table 3). This paradoxical action of GDEE might be due to its enzymatic conversion into glutamic acid during the $20 \mathrm{~min}$ incubation time.

Cell specificity of the increase in ${ }^{3} H-I P_{1}$ formation elicited by excitatory amino acids in primary cultures of cerebellar granule cells

To study the cell specificity of the increase in ${ }^{3} \mathrm{H}-\mathrm{IP}_{1}$ formation elicited by dicarboxylic amino acids, we have investigated the action of glutamic acid in cultures of either cerebellar astrocytes or cerebellar neurons pretreated with $50 \mu \mathrm{M}$ kainic acid for 18 hr. Such treatment causes a substantial loss in GABAergic interneurons, as is reflected by a $90 \%$ decrease in glutamic acid decarboxylase (GAD, EC 4.1.1.15) activity and by the disappearance of GAD-like immunoreactivity (data not shown) L-Glutamic acid $\left(10^{-4} \mathrm{M}\right)$ fails to stimulate inositol phospholipid hydrolysis in cultures of astrocytes (Table 4), but still substantially increases ${ }^{3} \mathrm{H}-\mathrm{IP}$, formation in cultures of cerebellar neu- rons pretreated with kainic acid (Table 4). This treatment changes the stimulatory action of L-glutamic acid on inositol phospholipid hydrolysis by less than $15 \%$.

\section{Discussion}

Recent evidence indicates that the hydrolysis of membrane inositol phospholipids is an important signal-transducing system for several neurotransmitters (for a review, see Michell, 1975). Presumably, a receptor-mediated activation of phospholipase $C$ hydrolyzes the polyphosphoinositides phosphatidylinositol4-phosphate and phosphatidylinositol-4,5-diphosphate into inositolphosphates and diacylglycerol. These compounds trigger a cascade of events that leads to mobilization of $\mathrm{Ca}^{2+}$ from intracellular stores, release of arachidonic acid from membrane phospholipids or from diacylglycerol, and stimulation of protein phosphorylation by activation of protein kinase C (Berridge, 1984; Michell, 1975; Nishizuka, 1984). The products IP ${ }_{2}$ and $\mathrm{IP}_{3}$ are rapidly dephosphorylated into IP ${ }_{1}$, which is recycled back

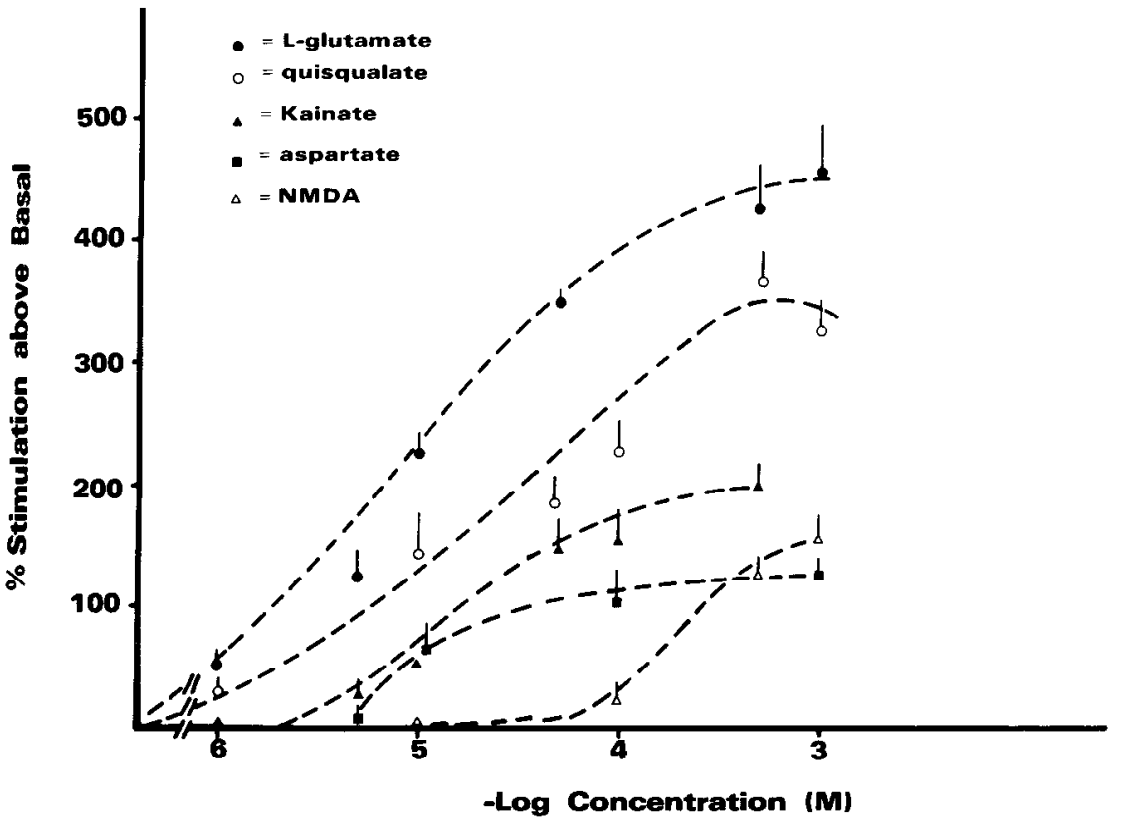

Figure 4. Dose-dependent accumulation of ${ }^{3} \mathrm{H}-\mathrm{IP}$ (expressed as percent stimulation above basal) elicited by various excitatory amino acid receptor agonists in primary cultures of cerebellar granule cells. Values are means + SEM of 4-12 determinations. 


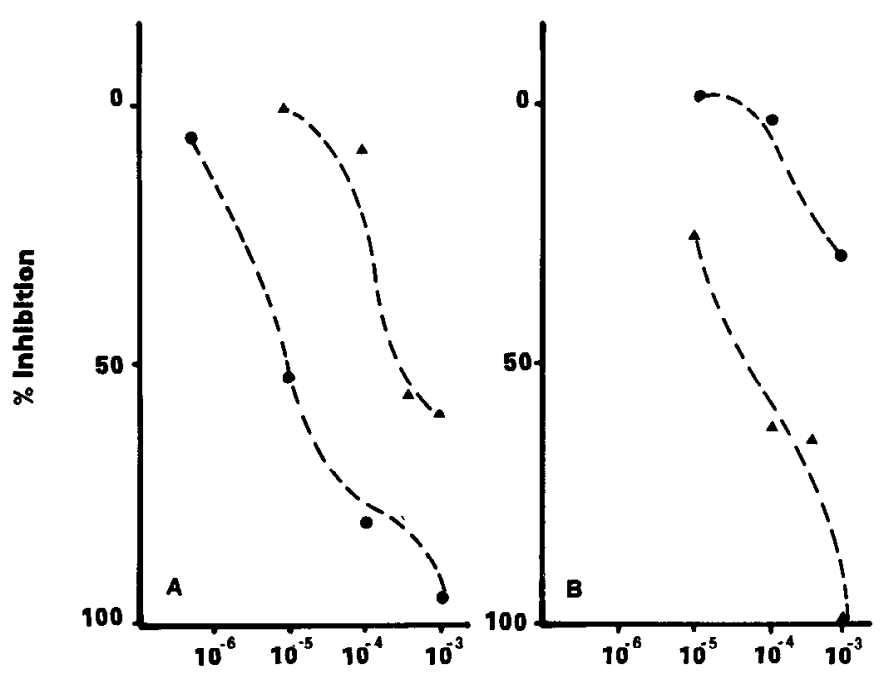

Figure 5. Dose-dependent inhibition of the stimulatory action of $5 \times$ $10^{-6} \mathrm{M}$ L-glutamic acid $(A)$ and $10^{-5} \mathrm{M}$ kainic acid $(B)$ on ${ }^{3} \mathrm{H}-\mathrm{IP}$, formation in primary cultures of cerebellar granule cells. $\Delta$, PDA; $\mathbf{O}$, D,L-APV.

to inositol for resynthesis of phosphatidylinositol. $\mathrm{Li}^{+}$blocks the conversion of $\mathrm{IP}_{1}$ into inositol by inhibiting the enzyme inositol-1-phosphatase (3.1.3.25; Allison et al., 1976). In the presence of $\mathrm{Li}^{+}$, the rate of accumulation of $\mathrm{IP}_{1}$ reflects the rate of hydrolysis of membrane inositol phospholipids (Berridge et al., 1982).

Excitatory amino acids activate inositol phospholipid metabolism in primary cultures of cerebellar granule cells. This action seems to be independent of an influx of extracellular $\mathrm{Ca}^{2+}$, since L-glutamic acid also stimulates the formation of the initial products $\mathrm{IP}_{2}$ and $\mathrm{IP}_{3}$ in the absence of extracellular $\mathrm{Ca}^{2+}$. In addition, quisqualic, aspartic, and $N$-methyl-D-aspartic acids enhance inositol phospholipid hydrolysis, but fail to increase substantially ${ }^{45} \mathrm{Ca}^{2+}$ uptake in primary cultures of cerebellar granule cells (Wroblewski et al., 1985). The lack of stimulation of ${ }^{3} \mathrm{H}-\mathrm{IP}_{1}$ formation by excitatory amino acids in $\mathrm{Ca}^{2+}$-free conditions is in agreement with previous reports (Kendall and Nahorski, 1984). It is possible that the conversion of $\mathrm{IP}_{3}$ and $\mathrm{IP}_{2}$ into $\mathrm{IP}_{1}$ or the direct formation of $\mathrm{IP}_{1}$ from phosphatidylinositol is dependent on an enhanced influx of extracellular $\mathrm{Ca}^{2+}$.

The stimulatory action of L-glutamic acid on inositol phospholipid hydrolysis is antagonized by APV, which is a potent and selective antagonist of the "NMDA" excitatory amino acid receptor subtype (for a review, see Foster and Fagg, 1984). However, the site whereby L-glutamic acid acts to enhance inositol phospholipid hydrolysis cannot be identified with the "NMDA" receptor, as defined by electrophysiological studies (Watkins and Evans, 1981). In fact, NMDA and the "NMDA" receptor agonists ibotenic and quinolinic acids are weak stimulants of ${ }^{3} \mathrm{H}-\mathrm{IP}_{1}$ formation (Table 2, Fig. 2). This apparent discrepancy suggests

Table 4. Glutamate-induced ${ }^{3} \mathrm{H}-\mathrm{IP}_{1}$ accumulation in primary cultures of cerebellar astrocytes or granule cells

\begin{tabular}{lcl} 
& $\begin{array}{l}{ }^{3} \mathrm{H}-\mathrm{IP}, \text { formation } \\
\text { (cpm/100 } \mu \mathrm{g} \text { prot.) }\end{array}$ \\
\cline { 2 - 3 } & Granule cells & Astrocytes \\
\hline Controls & $460 \pm 11(12)$ & $390 \pm 7(6)$ \\
L-Glutamic acid $\left(10^{-4} \mathrm{M}\right)$ & $2100 \pm 83(11)$ & $460 \pm 12(6)$
\end{tabular}

Values are mean \pm SEM of $6-12$ individual determinations.

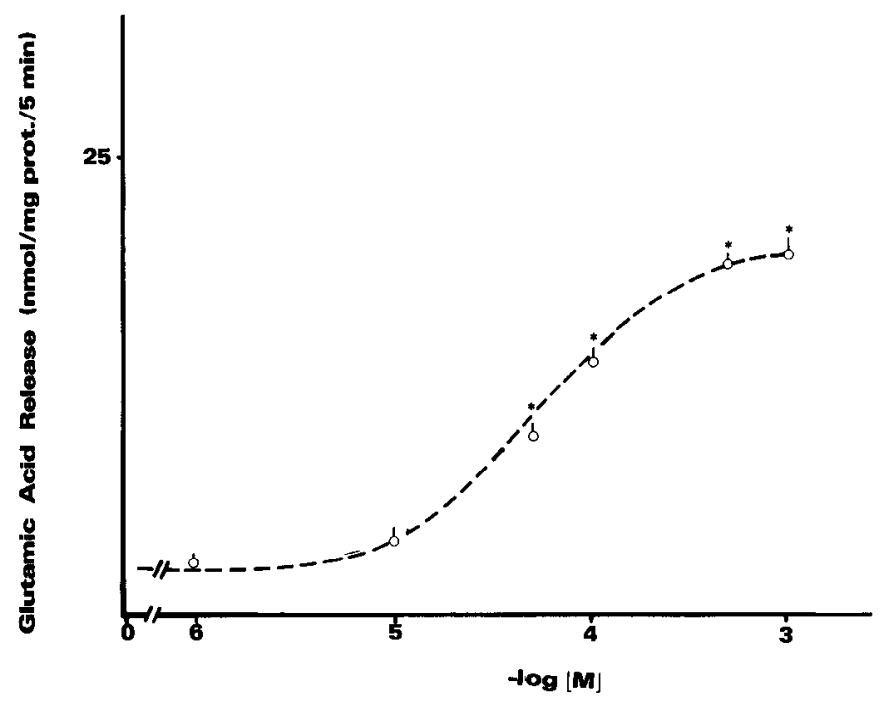

Figure 6. Dose-dependent stimulation of L-glutamic acid release by kainic acid in primary cultures of cerebellar granule cells. Values are means \pm SEM of 4-14 determinations.

that a receptor classification based upon electrophysiological criteria is inadequate for classifying the signal transduction stimulated by excitatory amino acids.

It appears that cerebellar granule cells in culture express a specific recognition site for excitatory amino acids that (1) is coupled with inositol phospholipid metabolism, (2) is preferentially activated by L-glutamic acid, (3) is sensitive to the inhibitory action of APV or $\gamma$-glutamylglycine, but (4) does not fall into any of the 3 major excitatory amino acid receptor subtypes defined by electrophysiological or ligand-binding data (Foster and Fagg, 1984).

The stimulatory action of low concentrations of kainic acid is preferentially antagonized by PDA and $\gamma$-glutamylglycine. This is consistent with the evidence that, among various excitatory amino acid receptor antagonists, only PDA and $\gamma$-glutamylglycine reduce the increase in cGMP content elicited by kainic acid in primary cultures of cerebellar granule cells (Novelli et al., unpublished observations). Hence, in addition to a L-glutamic acid-sensitive site, cerebellar granule cells express a kainic acid-sensitive site associated with inositol phospholipid metabolism. The stimulation of this site by kainic acid enhances glutamic acid release in cerebellar granule cells.

The stimulation of ${ }^{3} \mathrm{H}-\mathrm{IP}_{1}$ formation by quisqualic acid is insensitive to the antagonism of APV, PDA, and $\gamma$-glutamylglycine, which suggests that quisqualic acid activates inositol phospholipid metabolism through a site different from the ones that are preferentially activated by L-glutamic and kainic acids. However, the molecular mechanism whereby quisqualic acid

Table 5. Stimulation of ${ }^{3} \mathrm{H}-\mathrm{IP}_{1}$ accumulation elicited by L-glutamic acid in primary cultures of cerebellar neurons pretreated with kainic acid $(50 \mu \mathrm{M})$ for $18 \mathrm{hr}$ to selectively destroy GABAergic neurons

\begin{tabular}{|c|c|c|}
\hline & $\begin{array}{l}{ }^{3} \mathrm{H}-\mathrm{IP} \text {, formation } \\
(\mathrm{cpm} / 100 \mu \mathrm{g} \text { prot }\end{array}$ & \\
\hline & No pretreatment & $\begin{array}{l}\text { Kainic acid } \\
\text { pretreatment }\end{array}$ \\
\hline Control & $480 \pm 25(3)$ & $480 \pm 43(4)$ \\
\hline L-Glutamic acid $\left(10^{-4} \mathrm{M}\right)$ & $\begin{array}{l}1900 \pm 26(3) \\
(+298 \%)\end{array}$ & $\begin{array}{l}1700 \pm 68(4) \\
(+262 \%)\end{array}$ \\
\hline
\end{tabular}

Values are the mean \pm SEM of $(n)$ determinations. 
enhances inositol phospholipid hydrolysis is still unclear, since the action of quisqualic acid is resistant to all the antagonists we have tested, including GDEE, which is reported as a selective inhibitor of the "quisqualate" preferring receptor subtype (see Foster and Fagg, 1984).

In conclusion, we have shown that, in primary cultures of cerebellar granule cells, at least two different excitatory amino acid receptor subtypes, characterized by a differential sensitivity to the inhibitory action of APV and PDA, are associated with inositol phospholipid metabolism. L-Glutamic acid may act as a potent physiological agonist at the site preferentially inhibited by APV, whereas an endogenous compound, mimicking the action of kainic acid, might act as a physiological agonist at the site preferentially inhibited by PDA. Although the developing cerebellum has been shown to have unique properties with respect to the intracellular biochemical response to excitatory amino acid receptor activation, the stimulation of inositol phospholipid hydrolysis that we have shown is not a peculiar feature of cerebellar granule cells. We have recently observed that the activation of phosphatidylinositol metabolism by excitatory amino acids is a general response throughout the CNS during development (Nicoletti et al., 1986). The role of this signal transduction in the synaptic response to excitatory amino acids is currently under investigation.

\section{References}

Allison, J. H., M. E. Blisner, W. H. Holland, P. P. Hipps, and W. R. Sherman (1976) Increased brain myo-inositol-1-phosphate in lithium-treated rats. Biochem. Biophys. Res. Commun. 71: 664-670.

Berridge, M. J. (1984) Inositol triphosphate and diacylglycerol as second messengers. Biochem. J. 220: 345-360.

Berridge, M. J., C. P. Downes, and M. R. Hanley (1982) Lithium amplifies agonist-dependent phosphatidylinositol responses in brain and salivary glands. Biochem. J. 206: 587-595.

Brown, E., D. A. Kendall, and S. R. Nahorski (1984) Inositol phospholipid hydrolysis in rat cerebral cortical slices: Receptor characterization. J. Neurochem. 42: 1379-1387.

Einarsson, S., B. Josefsson, and S. Lagerkvist (1983) Determination of amino acids with 9-fluoroenylmethyl chloroformate and reversedphase high-performance liquid chromatography. J. Chromatogr. 282 : 609-618.
Foster, A. C., and G. E. Fagg (1984) Acidic amino acid binding sites in mammalian neuronal membranes: Their relationship to synaptic receptors. Brain Res. Rev. 7: 103-164.

Gallo, V., M. T. Ciotti, A. Coletti, F. Aloisi, and G. Levi (1982) Selective release of glutamate from cerebellar granule cells differentiating in culture. Proc. Natl. Acad. Sci. USA 79: 7919-7923.

Gallo, V., B. C. Wise, F. Vaccarino, and A. Guidotti (1985) $\gamma$-Aminobutyric acid- and benzodiazepine-induced modulation of [ $\left.{ }^{35} \mathrm{~S}\right]-$ $t$-butylbicyclophosphonothionate binding to cerebellar granule cells. J. Neurosci. 5: 2432-2438.

Kendall, D. A., and S. R. Nahorski (1984) Inositol phospholipid hydrolysis in rat cerebral cortical slices: II. Calcium requirement. J. Neurochem. 42: 1388-1394.

Lowry, O. H., N. J. Rosenbrough, A. L. Farr, and R. J. Randall (1951) Protein measurement with the folin phenol reagent. J. Biol. Chem. 193: 256-275.

Michell, R. H. (1975) Inositol phospholipids and cell surface receptor function. Biochim. Biophys. Acta 415: 81-147.

Nicoletti, F., J. L. Meek, M. Iadarola, D. M. Chuang, B. L. Roth, and E. Costa (1986) Coupling of inositol phospholipid metabolism with excitatory amino acid recognition sites in rat hippocampus. J. Neurochem. 40: 40-46.

Nicoletti, F., M. Iadarola, J. T. Wroblewski, and E. Costa (1986) Excitatory amino acid recognition sites coupled with inositol phospholipid metabolism: Developmental changes and interaction with 1-adrenoceptors. Proc. Natl. Acad. Sci. USA 83; 1931-1935.

Nichizuka, Y. (1984) Turnover of inositol phospholipids and signal transduction. Science 225: 1365-1370.

Novelli, A., F. Nicoletti, J. T. Wroblewski, H. Alho, E. Costa, and A. Guidotti (in press) Excitatory amino acid receptors coupled with guanylate cyclase in primary cultures of cerebellar granule cells. J. Neurosci.

Sandoval, M. E., and C. W. Cotman (1978) Evaluation of glutamate as a neurotransmitter of cerebellar parallel fibers. Neuroscience 3: 199-206.

Watkins, J. C., and R. H. Evans (1981) Excitatory amino acid transmitters. Annu. Rev. Pharmacol. Toxicol. 21: 165-204.

Woodhams, P. L., G. P. Wilkin, and R. Balasz (1981) Rat cerebellar cells in tissue culture. II. Immunocytochemical identification of replicating cells in astrocyte enriched cultures. Dev. Neurosci. 4: 307310.

Wroblewski, J. T., F. Nicoletti, and E. Costa (1985) Different coupling of excitatory amino acid receptors with $\mathrm{Ca}^{2+}$ channels in primary cultures of cerebellar granule cells. Neuropharmacology 24: 919-921. 